\title{
Maria Pia fecit / feito por Maria Pia: obSE RVADA E ObSERVADORa. Algumas reflexões SOBRE QUESTÕES DE GÉNERO A PARTIR DO CASO da rainha Maria Pia, fotógrafa
}

\author{
Teresa Mendes Flores
}

\begin{abstract}
RESUMo
Este artigo discute alguns aspetos do estatuto das mulheres fotógrafas amadoras durante a viragem do século XIX para o século XX, a partir do caso da rainha portuguesa Maria Pia de Sabóia (1847-1911). Verificamos as dificuldades de proceder a esta historiografia de mulheres fotógrafas em Portugal, pela escassez de fontes e arquivos, e pela falta de interrogações sobre estas ausências e as suas razões. Estes factos têm contribuído para uma história da fotografia portuguesa que consiste numa sucessão de nomes masculinos de "grandes fotógrafos". Colocar questões sobre "a outra metade", alargar conceções de fotografia e incluir a diversidade das suas práticas poderá contribuir para percebermos as construções de género suscitadas pela prática fotográfica e as razões que dificultaram, neste período, o acesso das mulheres portuguesas a esta prática e à sua visibilidade pública.
\end{abstract}

Palavras-chave

Maria Pia; fotógrafas amadoras; género; cultura visual; história da fotografia portuguesa

\begin{abstract}
This article discusses some aspects of the status of women amateur photographers during the turn of the $19^{\text {th }}$ to $20^{\text {th }}$ centuries, considering the case of the Portuguese Queen Maria Pia of Savoy (1847-1911). We acknowledge the difficulties of making the historiography of women photographers in Portugal, due to the scarcity of sources and archives, and the lack of questions about these absences and their reasons. These facts have contributed to a history of photography in Portugal that consists of a succession of male names of "great photographers". Asking questions about "the other half", as well as broadening conceptions of photography to include the diversity of their practices may contribute to highlight the gender constructions raised by photographic practice. It also will help to understand the factors contributing to the limited access of Portuguese women to this practice and the lack of their public visibility, during this period.
\end{abstract}

KEYWORDS

Maria Pia; amateur photographers; gender; visual culture; history of Portuguese photography 
Mas, podem perguntar-se, nós pedimos-lhe para vir falar de mulheres e ficção - o que é que isso tem a ver com um quarto que seja só seu? (...) Uma mulher tem de ter dinheiro e um quarto que seja só seu para que possa escrever ficção. (Virginia Woolf, 1931, p. 5)

Maria Pia de Sabóia (1847-1911)' não teria falta de um quarto que fosse só seu para que pudesse dedicar-se às artes. A sua condição de rainha dava-lhe o direito a esses aposentos, descritos com grande minúcia, em fevereiro de 1865, pelo arquiteto responsável pelos trabalhos de redecoração do Palácio da Ajuda, o também fotógrafo, Joaquim Possidónio Narciso da Silva (1806-1896), que enalteceu, nesse texto, o bom gosto de Maria Pia: "vamos admirar o que ha de mais mimoso, rico e de melhor gosto, penetrando nos aposentos de sua magestade a rainha" (Silva, 1865). O arquiteto não descreve, nesse texto, o ateliê de pintura da rainha, no andar de cima, nem os armários e diversas salas de arrumação, contíguas a estes espaços, onde se guardava e misturava o seu material de pintura e fotografia ${ }^{2}$. Por outro lado, uma certa independência económica resultava do seu estatuto de monarca, com uma renda atribuída à sua própria casa real e um gestor administrativo sob sua responsabilidade. Nos arquivos do Palácio da Ajuda, encontram-se diversas faturas das aquisições da rainha, onde se incluem os dispendiosos materiais para pintura e fotografia (câmaras fotográficas, placas sensíveis, químicos, acessórios de laboratório, etc.), adquiridos a importantes casas dessas especialidades, tanto portuguesas como estrangeiras (Andrade, 2011; Jardim, 2016). Maria Pia foi pintora e fotógrafa amadora, tal como diversos membros da sua família, mas as suas imagens raramente foram vistas fora dos circuitos domésticos.

Apesar de ver satisfeitas duas das condições básicas, segundo Virginia Woolf, para que uma mulher - qualquer pessoa, na verdade - pudesse desenvolver uma atividade artística (privacidade e independência económica), Maria Pia nunca foi reconhecida como "Rainha-artista", algo que, apesar de diversos constrangimentos, o seu filho, o Rei D. Carlos, obteve3. No campo da fotografia, Maria Pia teve alguma notoriedade já

\footnotetext{
' Maria Pia de Sabóia (1847-1911), quinta filha de Vítor Manuel (1820-1878), rei da Sardenha, e de Maria Adelaide de Habsburgo Lorena (1822-1855), arquiduquesa da Áustria, nasceu em Turim a 16 de outubro de 1847. Casou nessa cidade, por procuração, com o rei D. Luís I de Portugal, no dia 27 de setembro de 1862. A jovem rainha, de 14 anos, chega a Lisboa no dia 5 de outubro desse ano para o casamento religioso na igreja de São Domingos, perto do Rossio. Viverá em Portugal durante 48 anos. Sai após a implantação da República, precisamente a 5 de outubro de 1910. Morrerá, no ano seguinte, em Itália.

${ }^{2}$ Não existiriam ainda nessa data? Seja como for o ateliê fará parte do Palácio e é descrito por Maria do Rosário Jardim que se refere ao material de pintura e fotografia aí inventariado no arrolamento de bens, realizado pela república entre 1910 e 1913 (Jardim, 2016, p. 180).

${ }^{3}$ As historiadoras Raquel Henriques da Silva e Maria de Jesus Monge dedicam um livro à obra de pintura do rei D. Carlos (Silva \& Monge, 2007). As autoras abrem o seu texto, precisamente, documentando como o rei português obteve reconhecimento na sua própria época. Escrevem: "considerar que D. Carlos é uma figura relevante do naturalismo português - situando-se ao nível das personalidades consagradas de outros artistas da sua idade, como Carlos Reis ou Veloso Salgado - não é propriamente uma novidade. Nos anos de 189o, quando ele participou sistematicamente nas exposições do Grémio Artístico, a qualidade e originalidade da sua pintura foram reconhecidas por todos os sectores da crítica" (Silva \& Monge, 2007, p. 13). Isto não significava que o seu estatuto de rei não constituísse estranheza: “do sr. D. Carlos disse eu o ano passado que expusera as suas aguarelas, não como artista mas como rei (...) Com os pastéis , porém, que agora expôs, el-rei mostrou-me que com as ditas considerações transcendentes e filosóficas me estendi rasamente, dei raia!" (citado em Silva \& Monge, 2007, p. 15).
} 
que participou pelo menos numa exposição de fotografia, onde obteve um prémio (fora de concurso) e alguma atenção da imprensa. Trata-se da I Exposição Nacional de Photographias de Amadores que decorreu no salão "Portugal" da Sociedade de Geografia, em Lisboa, entre 31 de dezembro de 1899 e 22 de janeiro de 1900.

Contudo, foi preciso esperar 116 anos desde essa data, para que a sua "obra artística", assim assumida e identificada, fosse apresentada numa exposição. Tratou-se de Um Olhar Real. Obra artística da rainha D. Maria Pia - desenho, aguarela e fotografia, que decorreu na Galeria de Pintura do Rei D. Luís, no Palácio Nacional da Ajuda, entre 16 de dezembro de 2016 e 21 de abril de 2017. Como refere o seu diretor, José Alberto Ribeiro, "trata-se (...) de um acervo praticamente desconhecido, tal como a própria artista que se dá agora a conhecer numa faceta inédita e ao mesmo tempo reveladora da sensibilidade artística da monarca e do imenso espólio deixado no Paço da Ajuda, aquando da implantação da República, em 1910" (AA.VV., 2016, p. 9).

Neste texto, dedicado à temática da fotografia e género, pretendo partir do caso de Maria Pia para lançar algumas interrogações sobre estes fenómenos de persistente invisibilidade das práticas artísticas e fotográficas femininas ${ }^{4}$. Para isso, será importante estudar qual o lugar social da mulher-fotógrafa durante o século XIX e princípio do século XX, e que condições beneficiaram e prejudicaram a sua atuação em Portugal e no contexto europeu e norte-americano. Será, também, importante interrogar os próprios paradigmas historiográficos que, em Portugal, de um modo geral, não têm colocado estas questões, nem sentido a ausência de mulheres-fotógrafas. Se admitirmos que não existiram, quais as razões? Se, pelo contrário, existiram, onde estão? Quem foram?

Estas questões têm contribuído para o desenvolvimento de uma perspetiva crítica nas ciências sociais. Isto porque uma perspetiva feminista significa interrogar as razões sociais, culturais e até psicológicas desta ausência de (tantas) protagonistas femininas (Vicente, 2012).

As abordagens feministas, dentro da diversidade de feminismos (Tavares, 2011), não defendem um "machismo ao contrário", ou seja, a supremacia das mulheres sobre os homens (ainda é necessário esclarecer!). O que pretendem é contribuir para a igualdade de género dentro dos diversos campos de atuação. Este objetivo implicou uma crítica às noções inquestionadas de sujeito e objeto do conhecimento. Até às críticas feministas, especialmente da "segunda-vaga", nas décadas de 1960 e 1970, eram noções praticamente consideradas instâncias a priori e "sem género"- ou seja, recaindo sobre a norma da "masculinidade universal" (Collin, 2010). Por ação dos movimentos feministas, num contexto crítico marcado pelo marxismo, pelo pós-estruturalismo e pela psicanálise, as diversas ciências sociais tiveram que dirigir a sua atenção para o fenómeno da constituição social e histórica dos géneros e das subjetividades e politizar o seu próprio lugar enquanto saberes científicos (Nochlin, 1988; Pollock, 1987; Mulvey, 1989). É neste

\footnotetext{
${ }_{4}$ O espólio de Maria Pia ainda não se encontra catalogado de modo a ser consultado pelo público. Recorri às imagens que estão acessíveis na base de dados MatrizPix e ao catálogo da exposição referida. Agradeço à autora Maria do Rosário Jardim pelas preciosas informações do seu artigo. A autora menciona que o Arrolamento realizado pela República indicava a existência de 300 fotografias atribuídas à rainha.
} 
contexto que também emergem as questões da visualidade e da cultura visual como constituintes históricas da subjetividade e do género. Questões como "quem olha?", "quem tem o direito a olhar?", "Quem é visto?", "Como se distribuem os poderes do ver e do ser visto?", "o que se pode ver e mostrar?" ou "o que se deve esconder?" , também têm género. Estas interrogações estiveram na origem desta disciplina (ou indisciplina, como lhe chamou W.J.T. Mitchell, 1995), e contribuíram para implementar uma visão crítica da história da fotografia e dos média óticos (Naomi, 1994; Wells, 2003; Nameghy e González, 2013).

\section{QUEM NÃO APARECE, ESQUECE: AS DIFICULDADES DE UMA HISTÓRIA CRÍTICA DA FOTOGRAFIA PORTUGUESA}

Se bem que os estudos sobre as mulheres em Portugal têm progredido em diversos campos, a sua influência é muito mitigada na historiografia da fotografia. As questões de género, em vez de serem acolhidas como válidas, são frequentemente motivo de desvalorização, negação e até irritação.

Se considerarmos a história generalista de referência, que é História da imagem fotográfica em Portugal-1839-1997, de António Sena, publicada em 1998, a grande maioria dos autores referidos são homens. $O$ mesmo se passa quanto às imagens publicadas. Em toda a obra são referidas (no texto principal) 16 fotógrafas, entre centenas de autores masculinos. Dessas, temos quatro estrangeiras contemporâneas (Margareth Monk; a também cineasta Agnes Varda; Sabine Weiss e Alma Lavenson) e oito portuguesas: Helena Almeida (n.1934), Maria Madalena Soares de Azevedo, Auzenda Coelho de Castro, Alice Gentil Martins, Inês Gonçalves (n.1964), Teresa Siza (n.1948) e Júlia Ventura (n. 1952). Apenas Helena Almeida vê publicadas três séries de imagens (Pintura Habitada, 1977: Sena, 1998, p. 312; Desenho Habitado, 1976: Sena, 1998, p. 315; La Maison, 1984, Sena, 1998, p. 318). Podemos acrescentar um $17^{\circ}$ nome, se incluirmos a imagem científica publicada na página 353, da cientista Hanna Damásio (n.1943).

Do século XIX e primeira metade do século XX, surgem apenas quatro nomes: Madame Fritz, Margarida Relvas (1867-1930), Maria Pia (1847-1911) e Maria da Conceição Lemos de Magalhães (1863-1949). Desta autora, publicam-se três imagens de 1908, provavelmente da coleção do autor, que parece apreciá-las particularmente (Interior de aldeia: Sena, 1998, pp.194; Efeitos de Nuvem: Sena, 1998, pp. 207; Na Eira: Sena, 1998, pp. 217) ${ }^{5}$. Dada a baliza temporal, também em Tesouros da fotografia portuguesa do Século XIX, de Emília Tavares e Margarida Medeiros (2015), apenas surgem Maria Pia e Margarida Relvas, e se naturaliza esta escassez (não é uma questão).

Para António Sena e face ao seu vasto arquivo-coleção de fotografia portuguesa, a prática fotográfica não terá proliferado entre as mulheres portuguesas até à II Guerra Mundial, já que:

\footnotetext{
${ }^{5}$ Em 294 ilustrações que a obra publica, sete imagens têm mulheres autoras. Uma percentagem de 2,3\%. Muitas pessoas defendem, e bem, que o género não deve ser critério para a seleção das imagens significativas da história. Contudo, não deixa de ser surpreendente que essa "qualidade" recaia sempre "naturalmente" em autores masculinos. Esse desequilíbrio gritante merece ser debatido.
} 
Maria da Conceição Lemos de Magalhães é um caso raro, até 1940, de uma mulher ligada à fotografia em Portugal [além de Madame Fritz, 90 anos antes]. Esclareça-se que a sua atividade se desenvolveu desde 1905 até cerca de 1915, e que não se limitou ao simples disparo de uma máquina. Pelo contrário, interessava-se pelo seu tratamento laboratorial e dedicava-se ao estudo da química fotográfica. As proximidades com a obra pictórica de uma sua contemporânea, Aurélia de Sousa (1866-1922), não são também improváveis (...). As imagens contaminam-se. (Sena, 1998, p. 217)

Percebe-se, pelo excerto, que o autor foi sensível à questão das mulheres fotógrafas, já que enuncia a questão e reconhece que praticamente não existem e são "um caso raro". Curioso é o esclarecimento que sente necessidade de acrescentar: este vai no sentido de evidenciar que estamos perante uma mulher que faz parte dos "verdadeiros fotógrafos", já que a autora "não se limitou ao simples disparo de uma máquina". Podemos depreender que a necessidade deste esclarecimento só se justifica em face da expetativa comum (?) de que as mulheres portuguesas se limitariam a "carregar no botão". Nos imensos casos de autores masculinos deste livro, esse aditamento não é considerado necessário. É evidente que o comentário de Sena pretende ser abonatório do trabalho desta fotógrafa. No conjunto, parece sugerir, então, que as mulheres apenas teriam uma prática doméstica.

E se, como refere António Sena, as coisas mudaram em Portugal após a Segunda Guerra, como justificar a escassez de fotógrafas referidas no seu livro como significativas, desde então?

António Sena empreendeu um extraordinário trabalho de fixação de fontes documentais. Contudo, privilegiou a dimensão pública da fotografia. Não surgem álbuns, imagens privadas, snapshots de família e a dimensão popular da fotografia. Prevalece uma conceção modernista de artista em torno de uma essencialização do média. Como diz Rosenblum (1994), jogando com o vocábulo inglês, também aqui se confirma mais um caso de uma "His"- "story": uma estória-dele ou deles .

A história tem de ser documentada e os documentos desta história foram fundamentalmente relativos às práticas públicas de exibição, seja em exposições seja nas revistas. Acaba por se falar sobretudo nos nomes que se falaram em cada época. Quem não apareceu, esqueceu! Também o mercado do colecionismo valoriza os mais conhecidos, falados e comentados. As autorias bem determinadas e as mais reconhecidas (pelo sistema historiográfico) também constituíram, até há bem pouco tempo, o principal critério de formação dos arquivos públicos de fotografia, contribuindo para a perpetuação da sua feição máscula.

Considerar novas fontes, incluindo arquivos privados familiares e imagens pobres, formatadas, massemediáticas, resultantes de uma cultura popular, "desenterrará" provavelmente mais fotógrafas. Além disso, valerá a pena olhar as velhas fontes com novos olhos e novas interrogações ${ }^{6}$. Mesmo admitindo que Sena tem razão em considerar que as fotógrafas foram raras ou inexistentes, dada a masculinidade dos arquivos, é sempre

\footnotetext{
${ }^{6}$ Caso da exposição sobre os álbuns fotográficos de D. Amélia (AA.VV., 2015).
} 
preciso interrogar as políticas de visualidade que estruturaram as práticas da visão e as formações discursivas desses arquivos, como fenómenos ativos de construção social dos lugares de género, étnicos e de classe de cada um e de cada uma. Sobre esses processos sociais devem rezar as histórias.

\section{Feito por Maria Pia}

Maria Pia é uma das poucas autoras mencionadas em História da imagem fotográfica em Portugal, e isso acontece devido à sua participação na I Exposição Nacional de Photographias de Amadores, de 1899, já referida. Nesta data é provável que já se dedicasse à fotografia há pelo menos uma década. Segundo Maria do Rosário Jardim as primeiras provas assinadas que hoje se encontram no acervo do Palácio da Ajuda, datam de 1892 (Jardim, 2016, p. 170) (Figura 1). Por sua vez, os cadernos dos criados particulares da rainha Maria Pia documentam a sua regular atividade fotográfica, em particular a partir de 1889, ano da morte de D. Luís. O seu estatuto muda nessa altura e a sua disponibilidade aumenta. Um fator importante para a criação artística e para a fotografia em particular, sempre associada a passeios e a uma certa flânerie, uma forma do olhar deambulante e rápido, que estava na moda.

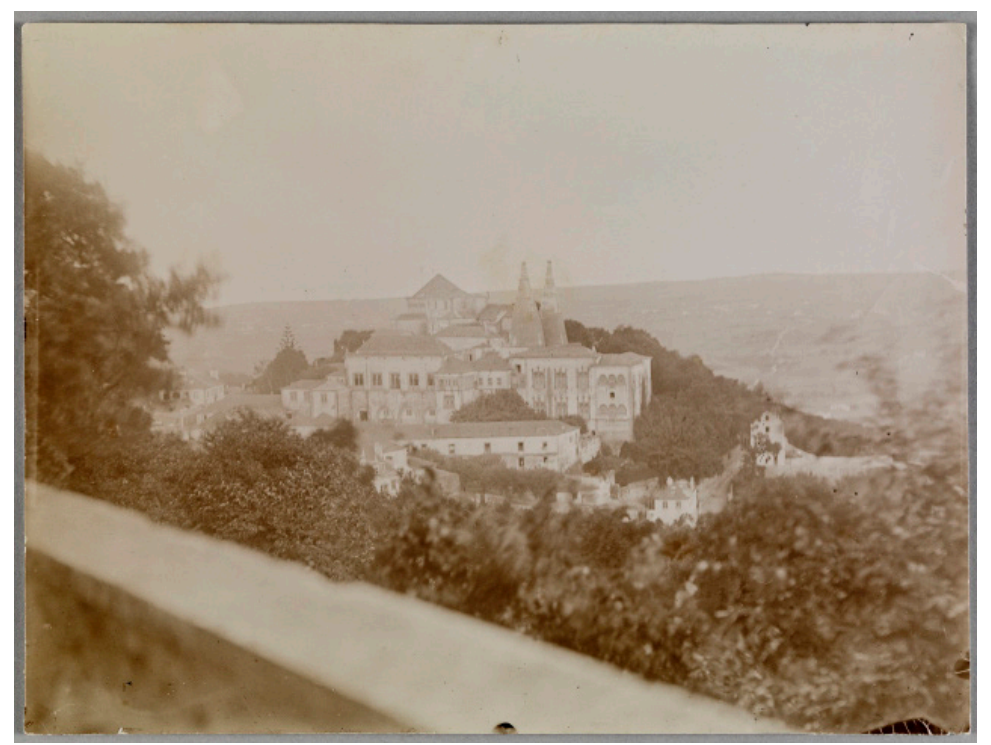

Figura 1: Real Paço de Sintra. Maria Pia, 1892. Prova positiva em gelatina sal e prata, em suporte de papel. 20,9x15,7 cm. Inv. PNA 62334

Fonte: Palácio Nacional da Ajuda, DGCP/ADF. Reprodução fotográfica de Luísa Oliveira

A sua educação foi, evidentemente, esmerada e está profusamente documentada $(\mathrm{Vaz}, 2016)$. O mesmo não acontece quanto à sua aprendizagem de fotografia. Mas, assim como teve professores particulares de desenho e pintura, uma situação frequente para homens e mulheres da sua classe, o mesmo pode ter acontecido para a fotografia. Sabe-se que D. Luís teve um professor de fotografia”.

7 No Diário de Notícias de julho de 1874, pode ler-se: "estando a família real em Queluz, a Rainha dedica-se à escultura (...) e D. Luís dedica-se à fotografia sob direção do fotógrafo Oliveira" (citado em Jardim, 2016, p. 170). 
Também parece claro que esta aprendizagem da fotografia surge no contexto da sua atividade enquanto artista plástica amadora. Um estatuto que decorria em muito da aprendizagem feita em casa por professores particulares e do universo que era atribuído às mulheres. Sandra Leandro escreve sobre as artistas do início do século XX e refere o estatuto que as artes desempenhavam na educação das mulheres ricas como forma de status: "prática de uma prenda feminina muito adequada a senhoras com posses, era forma de figurar e fazer figura, acrescentando presença e talvez personalidade - um modo de apresentação à sociedade" (Leandro, 2011, p. 272).

Embora fosse esse o sentido social, um tanto limitativo, que conduzia a oportunidades de formação, o certo é que muitas mulheres, como Maria Pia, aproveitaram essa formação para ter com as artes uma relação genuína e séria (Figura 2). Mesmo que nunca profissional. Mas nas artes plásticas tradicionais como na fotografia o estatuto de amador/a era prezado e tinha os seus circuitos expositivos próprios.

"Maria Pia ...fecit" ou simplesmente MP F" é a assinatura que se encontra inscrita a lápis no verso de muitas das imagens fotográficas do seu espólio. Este cuidado com a assinatura evidencia a valorização dada à fotografia e expressa a importância que the atribui enquanto arte autónoma. Permite-nos também considerar que Maria Pia não professava, certamente, a célebre posição do poeta francês Baudelaire, para quem a fotografia seria uma mera técnica auxiliar, "serva das artes e das ciências" (Baudelaire, 1987).

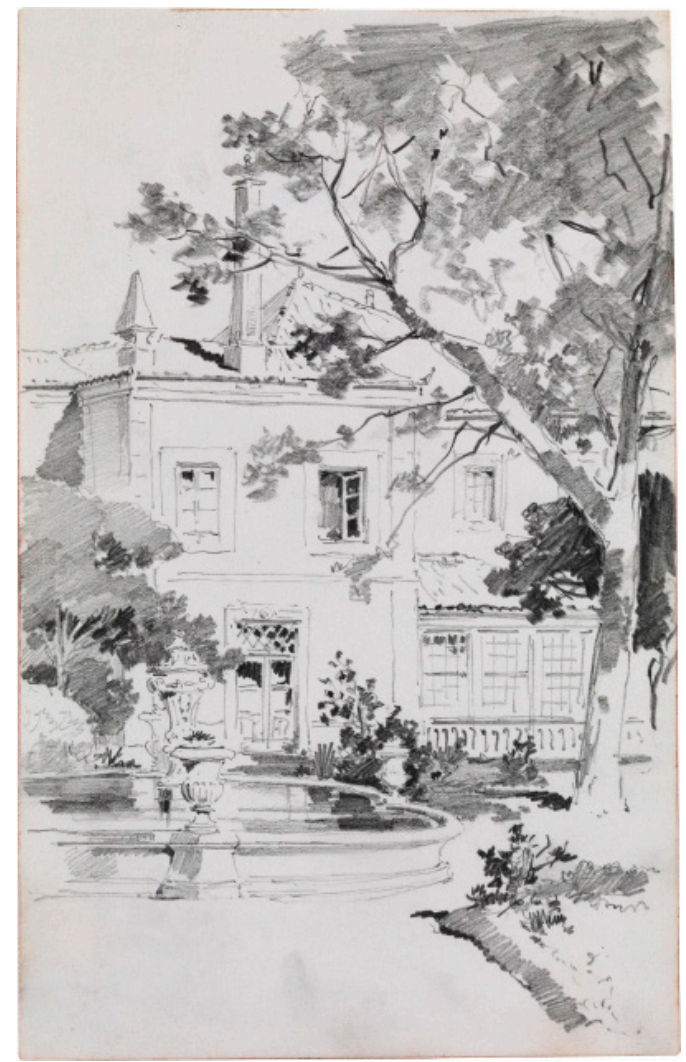

Figura 2: Palácio com tanque. Maria Pia, 1887-89. Lápis sobre papel. 14 × 22,7 cm. Inv. PNA 58279/19 Fonte: Palácio Nacional da Ajuda, DGCP/ADF. Reprodução fotográfica de José Paulo Ruas 
Em diversos casos, Maria Pia acrescenta a data e o local, identifica as iniciais das pessoas fotografadas, indica o número de cópias e o que fazer com elas. Anota aspetos relativos ao processamento laboratorial da imagem, às suas condições. Segundo Maria do Rosário Jardim estas informações mostram que "Maria Pia participava e geria com cuidado todas as fases do processo da fotografia" (Jardim, 2016, pp. 170-171). Também é conhecido pelo menos um laboratório fotográfico, o do Chalet Real, no Estoril.

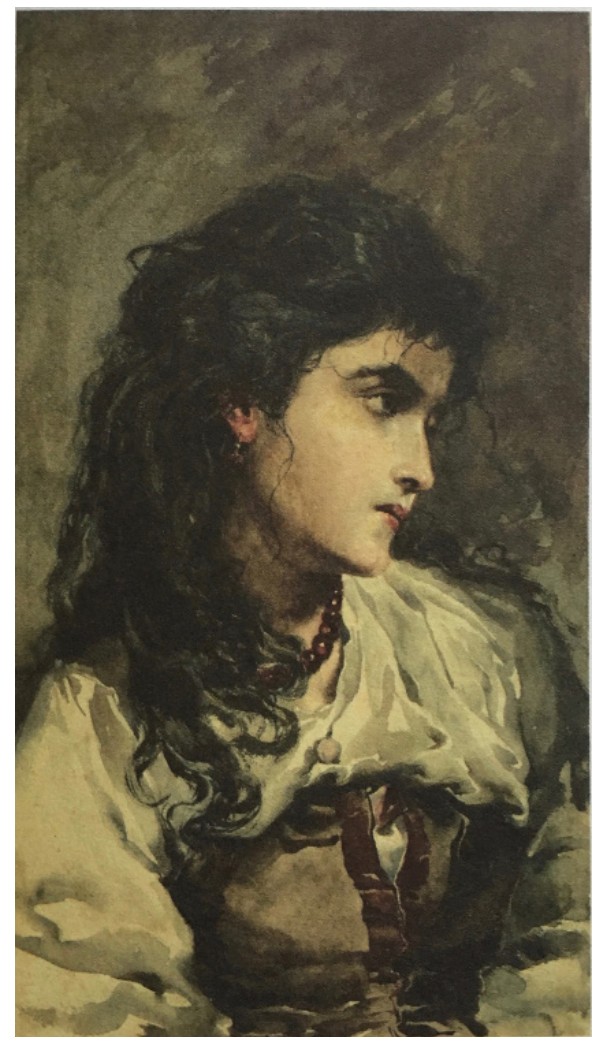

Figura 3: Cigana. Maria Pia, sem data. Aguarela sobre papel. 45,6x25,3 cm. Inv. PNA 4656 Fonte: Palácio Nacional da Ajuda, DGCP/ADF. Reprodução fotográfica de Teresa Mendes Flores (a partir de reprodução impressa)

\section{MARIA Pia...no laboratório?}

Não há dúvidas de que o Rei D. Carlos usava este laboratório. Levanta-se a questão de saber se Maria Pia o terá usado. Talvez pelo seu estatuto de rainha, Maria do Carmo Rebello de Andrade, na fotobiografia de Maria Pia, afirma: "não imaginamos D. Maria Pia nestes trabalhos de laboratório, certamente só D. Carlos fazia revelações" (Andrade, 2011, p. 165). Mas, porque "não imaginamos?". O saber e a oportunidade não faltavam a Maria Pia. Esse saber é pressuposto pela bibliografia sobre fotografia que a rainha comprava $^{8}$. A oportunidade associa-se ao contexto social da época. Era frequente entre os fotógrafos amadores, incluindo os aristocratas, a dedicação a todas as fases do processo.

\footnotetext{
${ }^{8}$ Maria do Rosário Jardim refere no seu artigo "o acesso a revistas e manuais de referência, onde se incluía (...) o conhecido Tratado Geral de Photographia Theorico e Prático, de 1891, de Arnaldo Fonseca, ou autores estrangeiros como Alphonso Davanne, La Photographie: traité théorique et pratique, de 1886-1888, P. Fabre-Domergue, Guide du Photographe et de l'amateur photographe, de 1888" (Jardim, 2016, p. 170).
} 
É verdade que estamos já numa fase de forte profissionalização da prática fotográfica, responsável pela enorme expansão do setor, que também se terá verificado em Portugal ${ }^{9}$. Comprar chapas previamente emulsionadas para a exposição e papéis sensíveis para as impressões tornou-se prática corrente e muito vantajosa. Mas, entre quem desenvolvia ambições artísticas ou simplesmente exigia maior qualidade das imagens, era comum o desejo de controlar por si próprio a realização da revelação e das provas em papel.

Não parece ter sido diferente para as fotógrafas amadoras. Pelo menos entre inglesas e americanas, a julgar pelo debate que se gerou nos jornais Photographic News, Eye e American Amateur Photographer, em dezembro de 1889, a propósito da conveniência ou não de admitir mulheres nos clubes de fotografia. A grande maioria desses clubes aceita mulheres como membros, mas alguns recusaram-nas alegando, entre outras objeções, que seria um prejuízo para a reputação das senhoras partilharem o laboratório com homens que não fossem seus maridos. Ou que obrigaria os membros masculinos a alterarem os seus comportamentos, não bebendo, nem fumando, nem usando linguagem inapropriada.

Catherine Weed Barnes (1851-1913), membro da Society of Amateur Photographers of New York, e ativista dos direitos das mulheres fotógrafas, responde com a defesa da igualdade:

será que este senhor considera o clube fotográfico um local que não pode ser frequentado por uma senhora sem que esta perca o seu auto-respeito ou o respeito dos outros? Porque é que essa circunstância há-de ser mais pesada para um sexo do que para o outro? Este senhor não diz que as mulheres não fazem um bom trabalho, mas deseja recusar-lhes as vantagens que professa serem necessárias para o seu próprio sexo. Elas podem trabalhar, mas devem fazê-lo da forma mais difícil, e perder o confronto mental com os seus irmãos. Este trabalho [fotográfico] em nenhum sentido deprecia a dignidade feminina, e é tão digno dela quanto dele. (Barnes, 1889, p. 224)

Da sua própria experiência também se depreende que era comum a prática laboratorial entre as mulheres fotógrafas. Usar o laboratório dos clubes era uma das vantagens para qualquer membro. Escreve Barnes:

na minha própria experiência, verifiquei que aqueles senhores que por acaso se viram na circunstância de estarem no laboratório ao mesmo tempo que eu, pareceram não sentir qualquer dificuldade em apagar os seus cigarros e tirar os seus chapéus enquanto eu permaneci no espaço. Por outras palavras, eles não sentiram que fosse uma dificuldade comportarem-se como cavalheiros. (Barnes, 1889, dezembro, p. 223)

\footnotetext{
9 Soares d'Andrade, diretor do Echo Photographico, agradece aos subscritores no início do seu quarto ano de publicação a fidelidade com as assinaturas e comenta que são cerca de 3 milhares de assinantes: “D'entre os tres milhares d'assignantes que nos teem acompanhado até hoje qual será o que não nos acompanhará n'esta bella cruzada que com tanta pontualidade temos conseguido, graças a essa magnífica protecção, pouco vulgar no nosso meio inculto (...)?” (Editorial, 1909, p. 2)
} 


\section{E acrescenta:}

a fotografia é um trabalho peculiarmente adequado às senhoras (...).Deixem-nas ter informação útil e ajuda prática onde quer que seja, e existem sociedades [de fotografia] que estão dispostas a dar-lhas. Digo, então, a todas as sociedades [fotográficas] para nos darem um campo justo e nenhum favor; deixem-nos ganhar as nossas esporas lado a lado com os nossos irmãos, e o resultado assim obtido merecerá todo o incómodo requerido. O dia virá, e virá em breve, em que apenas uma questão será feita em relação a qualquer trabalho fotográfico - "Está bem feito?". (Barnes, 1889, dezembro, p. 224)

A participação das mulheres em todas as fases da fotografia é mencionada também numa notícia do New York Times, de junho de 1890:

o grande número de raparigas apanhadas esta primavera pela mania-fotográfica é assinalável. Raparigas a nivelar os tripés das suas câmaras, a carregar nos botões das detetivas e das câmaras de mão são uma visão frequente no Parque e lá fora, nos subúrbios da cidade. Muitas delas estão neste assunto da fotografia com um louvável zelo, e não se contentam simplesmente em manobrar a câmara, mas estão a revelar as suas placas e até a fazer os seus próprios líquidos de revelação. (Photographers at Work, Young Women Becoming Enthusiastic Over the Art, 1890, p.8)

Num artigo com o sugestivo título "Women Who Press the Button" [Mulheres que carregam no botão] ${ }^{10}$, do mesmo jornal, adiantam-se as razões para este zelo: "as muIheres [fotógrafas] mais bem sucedidas fazem elas próprias todo o trabalho - revelação, impressão, etc. - porque placas diferentes necessitam tratamentos diferentes, de acordo com o tempo de exposição que tiveram - o qual, claro, é melhor conhecido por quem tirou a fotografia" (Women Who Press the Button, 1893, p. 18).

É verdade que numa notícia do jornal português Echo Photographico (1906-1913), num artigo intitulado "A mulher e a photographia" (1909, fevereiro, pp. 18-19), o articulista protesta contra o atraso do país, por não ser comum ver-se em Portugal mulheres com câmaras a tiracolo. Curiosamente, refere também a linguagem imprópria dos homens para com uma fotógrafa inglesa que passava nas ruas de Lisboa:

n'esta terra, infelizmente, quando se vê alguem com um apparelho photographico, não ha basbaque que não olhe, nem parvoide que não jogue o seu dito: "Tiras-me o retrato ?". Ao vermos a miss lembramo-nos imediatamente de que para uma senhora portugueza, o porte de tal apparelho seria coisa extraordinaria e jámais vista! (A mulher e a fotografia, 1909, pp. 18-19)

Contudo, sendo a corte portuguesa moldada por influências estrangeiras, e sendo aí comum a participação feminina em todas as fases do processo fotográfico, não

\footnotetext{
${ }^{10}$ Alusão ao famoso anúncio da marca Kodak.
} 
seria pois, estranha a participação de Maria Pia nos trabalhos de laboratório. Mesmo tratando-se de uma aristocrata. Essa condição social dava-lhe, aliás, o privilégio de ter o seu próprio laboratório e não estar, portanto, sujeita a quaisquer dos referidos constrangimentos.

\title{
UMA ATIVIDADE “PECULIARMENTE ADEQUADA ÀS MULHERES"
}

Embora uma atividade tecnológica, a fotografia foi desde o início entendida como adequada às mulheres. Seja porque se considerava comparativamente mais fácil que as outras artes, seja por se considerar mais próxima das artes manuais e aplicadas, como ramo das artes gráficas, ou pela relação com outras práticas ligadas a atividades contemplativas, como os passeios por entre a natureza "para ver vistas". Estes passeios "por entre a natureza" moldaram a educação de aristocratas, homens e mulheres, desde o século XVIII (Hunt, 2002). Era comum levarem-se cameras obscuras e vidros de claude, dispositivos que permitiam a transformação de um lugar numa imagem mais vívida e espetacular. A partir de 1804, ano da sua invenção, levavam-se cameras claras de Wollaston (1766-1828) para auxiliar nos desenhos. O desenho era incentivado para registo das observações e como forma de educar o gosto estético, que tinha nas formas naturais o seu modelo. Todos estes dispositivos técnicos contribuíam para melhorar a observação e incrementar o conhecimento da natureza, com incidências tanto científicas quanto estéticas (Mendes Flores, 2016). É na esteira desta tradição que surge a fotografia. No mesmo artigo do New York Times, de 1890, citado em cima, explicava-se isto mesmo:

\begin{abstract}
Os hábitos de observação são frequentemente implantados na mente através da tomada de vistas que nunca teria sido melhorada se não fosse esta prática [fotográfica]. O trabalho é limpo e saudável. Os vagabundos do ar livre à procura do belo e do artístico na natureza ficam revigorados e mais fortes, ao passo que a revelação das placas exige cuidado e grande atenção. (Photographers at Work, Young Women Becoming Enthusiastic Over the Art, 189o, p. 8)
\end{abstract}

Trabalhos recentes (sobretudo estrangeiros) têm sublinhado o importante papel das mulheres desde o início da fotografia. São exemplos Constance Fox Talbot (18111880), mulher do inventor inglês, e um grupo vasto de mulheres dessa família; Genevieve-Elizabeth Disdéri (1817-1878), mulher do famoso inventor da carte de visite, ou a botânica Anne Atkins (1799-1871). Para além das pioneiras, desde cedo várias mulheres se estabeleceram em nome próprio ou, mais frequentemente, em parceria com os maridos, como fotógrafas profissionais. Viúvas que tomaram conta de estúdios fotográficos, sendo elas próprias fotógrafas, e um conjunto de mulheres assistentes de laboratório e das mais diversas tarefas repetitivas dentro dos estúdios profissionais, são outras tantas dimensões desta relação das mulheres com a fotografia.

Em Portugal refira-se a investigação de Cátia Salvado Fonseca (2016), sobre o papel da família Relvas, como família de amadores, destacando Margarida Relvas. Na área 
das profissionais, Maria E. R. Campos, fazia-se anunciar, desde 1888, como a primeira fotógrafa profissional, com estúdio na Calçada do Duque, $\mathrm{n}^{\circ} 18$, em Lisboa.

Margaret Denny tem investigado estes casos no Reino Unido e EUA. Denny conclui que, pelo menos na cultura anglo-saxónica, "apesar das mulheres não estarem em pé de igualdade com os seus homólogos masculinos, as mulheres fotógrafas resistiram às expetativas de género e foram para além das pressupostas esferas separadas" (Denny, 2009, p. 802).

O apoio que a Rainha Victoria deu à fotografia é geralmente considerado marcante para a adoção da nova imagem por parte da aristocracia e da alta burguesia (Smith, 2015). A família real portuguesa é um desses casos.

Este é pois um gosto que circula entre as elites europeias. Expresso na frequência de estúdios profissionais, para verem produzidos os seus retratos, mas também enquanto praticantes. As monarquias tiraram partido político desta atividade, que nobilitaram.

É na prossecução desta tradição paisagística de conhecimento e usufruto da Natureza, que se pode compreender a atividade plástica de Maria Pia. Estoril, Sintra e Cascais, são os seus locais de eleição (Figuras 4 e 5). São destas regiões a maioria das suas fotografias, resultantes de grandes passeios, por vezes diários: "S[ua] M[agestade] esteve no jardim com a R[ainha] Margarida a fotografar" (citado em Jardim, 2016, p. 171); "depois de almoço esteve tirando S[ua] M[agestade] photographias"; ou "S[ua] M[agestade] não andou em bycicletas, sahiu da Peninha às 7 horas, andou tirando photographias e chegou ao Estoril às 9 horas da noute" (citado em Jardim, 2016, p. 174).

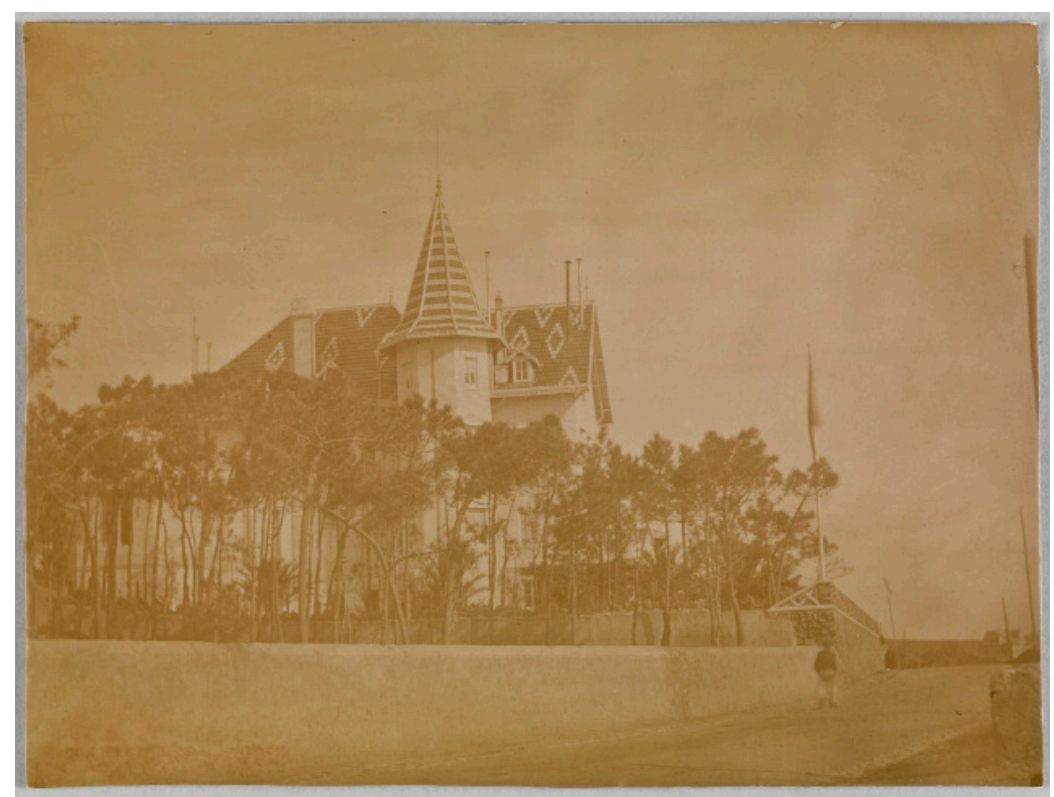

Figura 4: Paço Real do Estoril. Maria Pia, 26 de janeiro de 1894. Prova positiva em gelatina sal e prata em supor-te de papel, $15,8 \times 21 \mathrm{~cm}$. Inv. PNA. 62263

Fonte: Palácio Nacional da Ajuda, DGCP/ADF. Reprodução fotográfica de Luísa Oliveira 


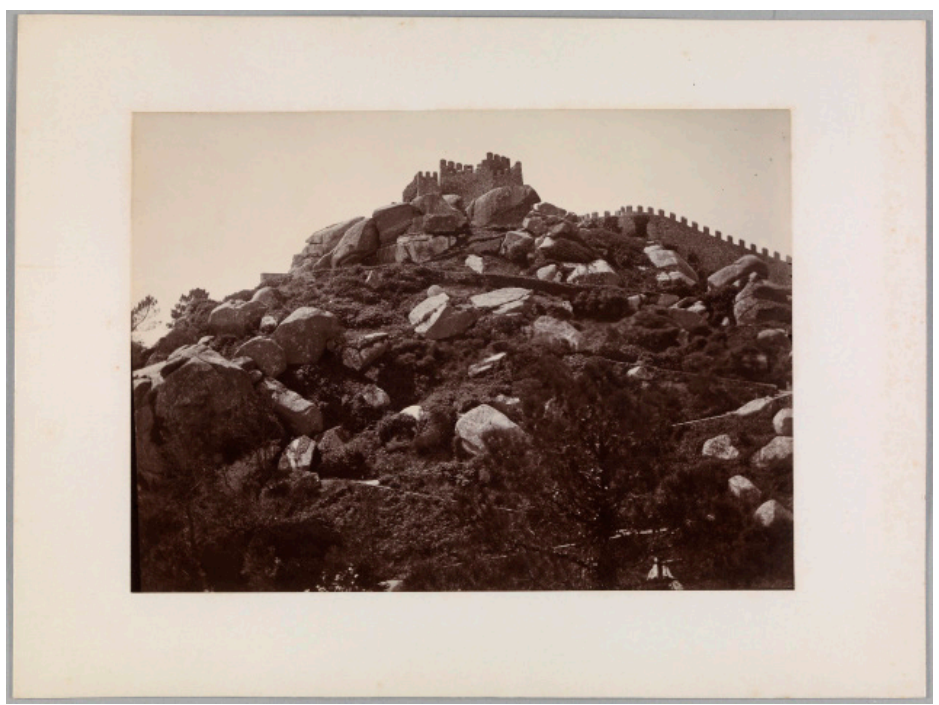

Figura 5: Sintra. Castelo dos Mouros. Maria Pia, c. 1893. Prova positiva em gelatina sal e prata, em suporte de pape com montagem em cartão. Imagem: $15 \times 20,6$ cm; Montagem: 21,3 x28,4 cm. Inv. PNA 62600 Fonte: Palácio Nacional da Ajuda, DGCP/ADF. Reprodução fotográfica de Luísa Oliveira

A adoção da bicicleta é mais um elemento que revela a sua atitude moderna, ou seja, o gosto pelas novidades técnicas, que rapidamente adota (Figura 6 ). Reflexo também do seu cosmopolitismo (Pallier, 2006; Pavão \& Cerqueira, 2007; Lopes, 2011).

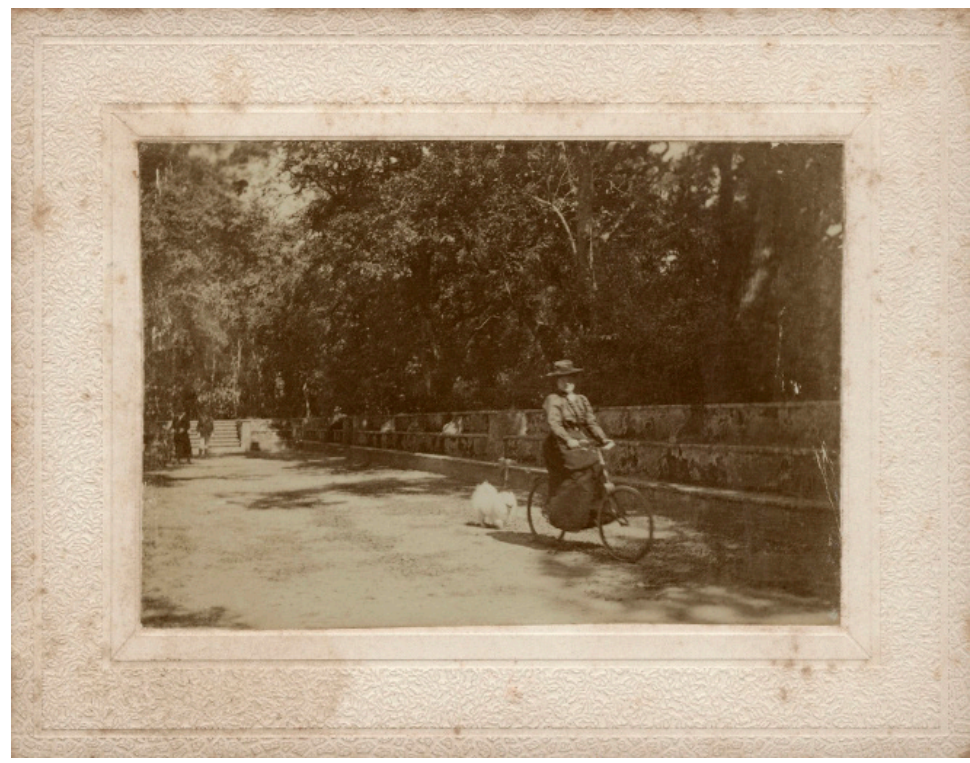

Figura 6: D. Maria a andar de bicicleta nos jardins do Palácio de Queluz. Autor(a) desconhecido(a). Imagem: 5,6 x $8,1 \mathrm{~cm}$; Montagem: $8,7 \times 11,2 \mathrm{~cm}$. Inv. PNA 45604

Fonte: Palácio Nacional da Ajuda, DGCP/ADF. Reprodução fotográfica de Luísa Oliveira

A associação entre fotografia e passeios de bicicleta é outra das marcas da cultura visual deste final de oitocentos. Ambas consideradas "sports" altamente recomendáveis para as senhoras, cujo tempo se queria ver ocupado em atividades edificantes para a alma (a observação atenta, base do conhecimento) e para o corpo (o exercício físico dos passeios de bicicleta ou a pé). E que não fossem muito difíceis (um argumento 
frequente). A popularidade da bicicleta "para as senhoras" surge na década de 1880, precisamente com um tipo de bicicleta, praticamente idêntico aos modelos contemporâneos, denominadas "bicicletas de segurança", pois eliminavam as desvantagens dos modelos de rodas elevadas, em que facilmente se caía.

A relação entre as duas atividades foi promovida por clubes especiais: os Photo-Vélôs. O Photo-Veló-Club do Porto editava, em 1899, um Boletim dirigido por Domingos Alvão (1872-1946). Este também dirigia a Escola Prática de Photographia do Photo-Velo- Club (situada na sede, no $n^{\circ} 120$ da Rua de Santa Catarina). O jornal Echo Photographico, tinha por sub-título "Jornal mensal de sport photographico" e durante os primeiros anos de publicação tinha na capa uma jovem mulher estereoscopista, com roupas mais práticas, caminhando por entre uma paisagem natural (Figura 7).

Apesar deste explícito apelo às mulheres, a que a capa do jornal parece convidar, entre 1906 e 1910 (anos que analisámos), encontrámos apenas menção a três fotógrafas. Na secção "Galeria dos Amadores Contemporâneos" apresenta-se um fotógrafo amador por mês". Aí se apresenta o perfil de duas fotógrafas: D. Maria C. Godinho e Nathalia Terra (respetivamente, Galeria de Amadores Contemporâneos: D. Maria C. Godinho, 1907, p. 19; Galeria de Amadores Contemporâneos: Nathalia Terra, 1908, p. 89). A terceira fotógrafa a surgir nas páginas do Echo Photographico, vê publicada uma imagem na seção dedicada à divulgação de imagens dos associados. Trata-se da imagem "Eu sou o tareco" de D. Júlia Gouveia Gonçalves, de Lisboa (Eu sou o tareco!, 1907, p. 76).

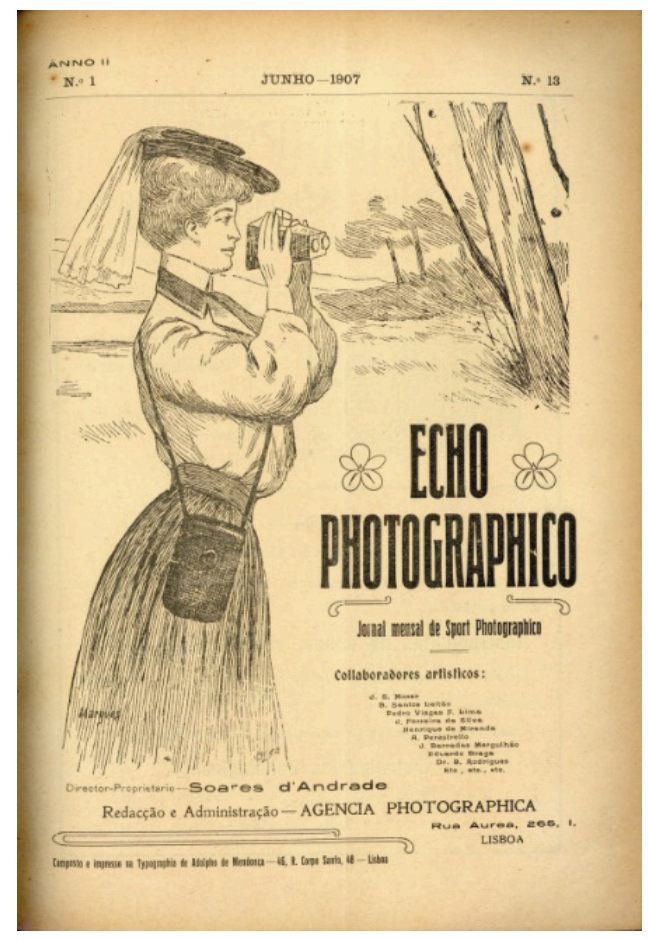

Figura 7: Capa do Echo Photographico. Ilustração de Marques Fonte: Echo Photographico, Jornal mensal de Sport Photographico, 1907, capa; Hemeroteca Municipal de Lisboa

\footnotetext{
"A secção inicia-se na edição $n^{\circ} 5$, em outubro de 1906, e dura ao longo de 27 edições. Termina na edição $n^{\circ} 33$, de fevereiro de 1909. Desses 27 fotógrafos, duas são mulheres (7,4\%).
} 
As duas autoras referidas como "Donas" serão certamente membros da aristocracia. O pai de Maria C. Godinho é referido também como amador, o que configura um caso típico de acesso das mulheres às artes. Nathalia Terra, açoriana, é apresentada como artista plástica. O caso das muitas artistas plásticas que Sandra Leandro (2011) apresenta (cerca de 36 , durante os poucos anos da $1^{\text {a }}$ República), a maioria consideradas amadoras, constitui um conjunto de pistas também para a fotografia. Será provável que algumas destas pintoras se dedicassem igualmente à fotografia. Veja-se o caso recentemente estudado da artista portuense Aurélia de Sousa (Vicente, 2016). Alice Rey Colaço, discípula do naturalista Carlos Reis, é a autora de algumas das fotografias conhecidas da sua irmã atriz, Amélia Rey Colaço (Barros, 2009). Por sua vez, Virgínia de Castro e Almeida escreveu e produziu para cinema, fundando a produtora Fortuna Filmes. Artista multifacetada, teria também feito fotografia? (Leandro, 2011, p. 313).

Um exemplo do modo como se encara a fotografia neste período, surge numa notícia de 1905, do Boletim Photographico (A rainha de Inglaterra, amadora de photographia, 1905, abril, p. 50). Citando o Diário de Notícias, apresenta-se a Rainha Alexandra de Inglaterra, em visita recente a Portugal, como uma "sportwoman" da fotografia, cujas imagens tinham contribuído para que se tivesse evitado a queda de uma ponte ${ }^{12}$ !

Para Maria Pia, tal como para muitas das artistas referidas por Leandro (2011), as artes visuais iriam além da mera recreação. Mas era pelo lado da "ocupação útil" que estas atividades eram incentivadas não apenas entre as mulheres, mas muito especialmente entre elas. Particularmente, entre as aristocratas. Até porque eram quem tinha mais meios económicos para tais práticas.

Nas fotografias de Maria Pia que estão acessíveis ao público, não surgem evidências de uma prática da fotografia de família, embora se documentem as atividades de grupo. São privilegiadas as paisagens naturais, tanto do campo como da orla marítima, o famoso género das "marinhas", muito apreciado na pintura da época. A atenção aos monumentos, aos interiores e detalhes decorativos característicos da arquitetura, revelam o seu olhar educado (Figura 8). Tal como relativamente à documentação das pessoas da região, um tema do agrado dos pintores naturalistas. A procura de "tipos" que transforma as pessoas do povo nos "outros", e nos "tipos" regionais, está de acordo com a ciência etnográfica e a antropologia e historiografia da época. Estas preocuparam-se em caracterizar as paisagens naturais e culturais das regiões e dos países, contribuindo para a afirmação de um cariz nacionalista, evidentemente, caro à monarquia.

\footnotetext{
${ }^{12}$ A notícia, transcrita do Diário de Notícias, é a seguinte: "educação completa de Sportwoman é photographa amadora. E as suas photographias já evitaram uma tremenda catastrophe: A Princeza Alexandra tendo tirado um instantaneo de uma ponte no districto de Sandringham, notou na prova uma inclinação do taboleiro da ponte. Attribuiu-a á machina photographica embora fosse um aparelho caro e de precisão; repetindo o instantaneo constatou a mesma inclinação. O Príncipe de Galles mandou, então, communicar o caso á Companhia e os engenheiros que fizeram uma vistoria immediatamente certificaram que a ponte ameaçava ruína e mais dia menos dia, sem o bom aviso da Princeza Alexandra, o abalo da locomotiva daria com ella em terra" (citada em A rainha de Inglaterra, amadora de photographia, 1905, abril, p. 50)
} 


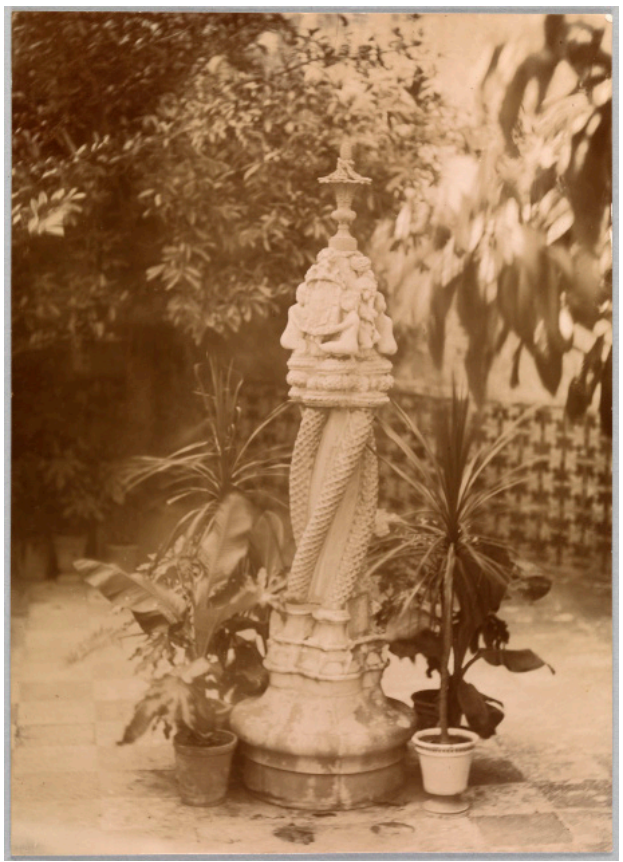

Figura 8: Paço Real de Sintra, pedra torsa. Maria Pia, 1892. Prova positiva em gelatina sal e prata, em suporte de papel, 18,1x12,9 cm. Inv. PNA. 61764

Fonte: Palácio Nacional da Ajuda, DGCP/ADF. Reprodução fotográfica de Luísa Oliveira

Pelo menos na amostra de imagens acessível ao público, não identificámos um interesse particular pela representação de espaços urbanos, nem uma abordagem subjetiva ou simbolista. A influência estética mais marcante é do movimento naturalista. Embora o pictorialismo possa ser considerado um desenvolvimento do naturalismo, distingue-se pela busca de imagens menos documentais e mais assumidamente interpretativas através do recurso a efeitos pictóricos irrepetíveis, que não entram no vocabulário de Maria Pia (o uso do desfocado intencional, a raspagem dos negativos, as impressões experimentando pigmentações diversas, goma bicromatada, platinotipia, etc.). O que de resto é congruente com o que se passava em termos estéticos no país.

\section{A EXPOSIÇÃo DE 1899}

A crítica a uma estética demasiado tradicional e pouco sintonizada com os últimos desenvolvimentos internacionais, surge no artigo de Arnaldo Fonseca sobre a "I Exposição Nacional de Photographias de Amadores", já referida, publicado no Boletim Photographico. Esta foi uma das (únicas?) exposições em que Maria Pia participou. Maria Pia terá aí apresentado 27 fotografias (Jardim, 2016, p. 180).

A crítica de Arnaldo Fonseca permite não apenas perceber que o trabalho de Maria Pia se insere nas práticas correntes em Portugal, como o papel vanguardista que era atribuído aos fotógrafos amadores (e às fotógrafas, nunca referidas) e que, segundo Arnaldo Fonseca, não estava a ser cumprido:

em toda a exposição o que se usou de maneira geral para a impressão de phototypos, foram os processos correntes de gelatina-chloreto e gelatina 
brometo. Em papeis de platina rarissimos ousaram imprimir as provas. Em papeis de bichromato suponho que nenhum. (...) Os papeis de platina revelados a glycerina, e os papeis preparados com gomma arabica bichromatada, prestam-se a uma revelação, a um depouillement a pincel, onde certos valores se podem attenuar e outros salientar; (...) póde claramente dar explendidos resultados, modificar a rigidez e fatalidade attribuidos á photographia. (...) Ninguem tambem, com uma unica excepção, explorou propositadamente oflou. Pelo contrario, houve na maioria, uma preoccupação de nitidez que esmaga por vezes a maior parte dos trabalhos. (A exposição nacional de photographia, 1900, p. 27)

"Paizagens e Marinhas" (Figura 9), e "Architectura e Monumentos" são os temas que encabeçam a lista de géneros, evidenciando a sua importância na prática amadora'3 . A fotografia de interiores, um subtema da "Architectura ", será também popular. Retratos de género e cenas orientalistas estão também presentes nesta edição. O Boletim Photographico publica uma das fotografias de Maria Pia, com um tema muito recorrente nas suas imagens: as árvores (Figura 10). Mas, mereceu pouco mais que uma atenção protocolar por parte de Arnaldo Fonseca: "S.M. a Rainha sra D. Maria Pia e sua alteza o sr. Infante, expõem quatro quadros com algumas provas brilhantes, sobretudo no que respeita á escolha do assumpto; entre ellas sobresahe a Praia do Guincho, onde uma onda cresce sob uma atmosphera de lindas nuvens" (A exposição nacional de photographia, 1900, p. 20).

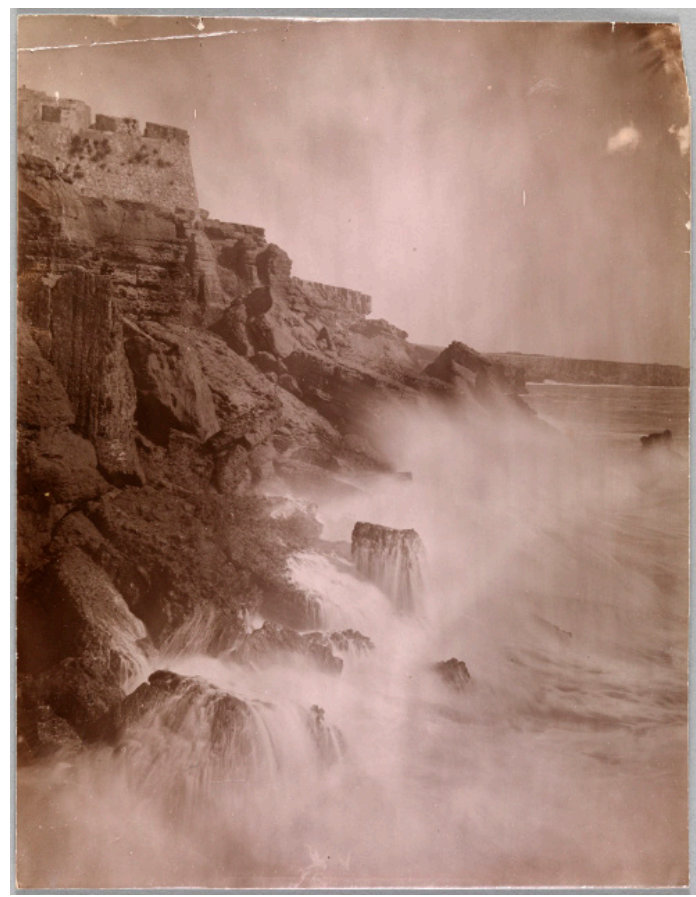

Figura 9: Arribas e Forte da Guia. Maria Pia, 19 de fevereiro de 1894. Prova positiva em gelatina sal e prata, em suporte de papel, 20,7 x 15,7 cm. Inv. PNA. 62195

Fonte: Palácio Nacional da Ajuda, DGCP/ADF. Reprodução fotográfica de Luísa Oliveira

\footnotetext{
${ }^{13}$ Isso mesmo confirma a notícia do jornal O Século (Exposição nacional de photographia, 1900, p. 1): "as paizagens e as marinhas são a parte predominante da exposição; sendo de lamentar que na grande maioria das primeiras lhes falte a animação da figura humana".
} 


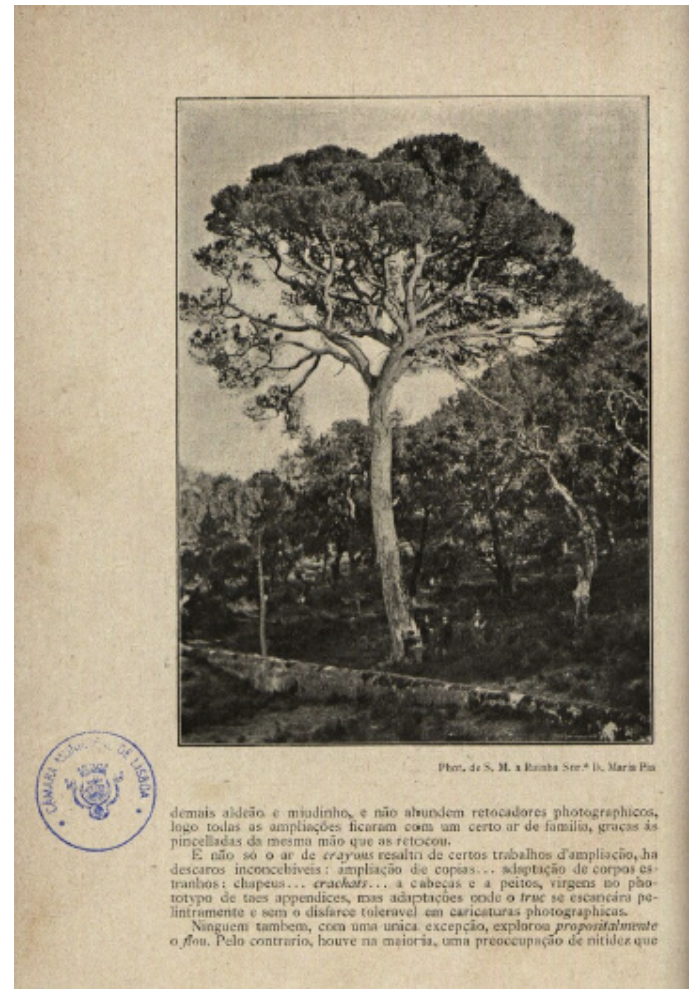

Figura 10: Página do Boletim Photographico com publicação de fotografia de Maria Pia, presente na I Exposição Nacional de Photographias de Amadores

Fonte: A exposição nacional de photographia, 1900, p. 28; Hemeroteca Municipal de Lisboa

Diferente é a posição do jornal Novidades: "Sua Magestade a rainha D. Maria Pia apresenta também photographias soberbas, representando o lançamento d'uma ponte em Tancos, diversos trechos do paço de Cintra e da praia de Cascais" (A Exposição Nacional de Photographias, 1899, s.p.). E genericamente sobre os trabalhos da família real diz serem "photographias magníficas pela nitidez, pela distribuição de luz e pela escolha do assumpto". O jornal O Século defende que a fotografia é uma arte e entre os exemplos de artistas inclui Maria Pia: "quem ha de negar que tal onda da rainha senhora D. Maria Pia (...) não são productos de espírito d'um gosto requintado, d'um temperamento de artista?" (Exposição nacional de photographia, 1900, p. 1).

Nesta exposição "cerca de 100 expositores concorreram ao certame" (Exposição nacional de photographia, 1900, p. 1) mas "os expositores [aprovados] foram (...) em número de 52" (A exposição nacional de photographia, 1900, p. 26). Destes, para além de Maria Pia, há menção a mais uma mulher, D. Luiza Thomar, que recebeu uma menção honrosa: "a sr ${ }^{a}$ D. Luiza Thomar expoz photominiaturas, e nisso foi a unica concorrente que abordou tal genero. As suas photominiaturas, reproducções de quadros, são de vistoso colorido" (A exposição nacional de photographia, 1900, p. 26).

De qualquer modo, se o reconhecimento do trabalho de Maria Pia parece ser genuíno, a atribuição de uma medalha de ouro, fora do concurso, não deixa de parecer protocolar ${ }^{14}$. A possibilidade de ser encarada como verdadeira artista é sempre balizada

14 "Salientam-se fora do concurso, as exposições d'El-Rei o sr. D. Carlos, de S.M. a sra D. Maria Pia e de S. Alteza o sr. Infante D. Affonso" (A exposição nacional de photographia, 1900, p. 19). 
pelo seu estatuto de rainha e de mulher. Não se evitavam, relativamente às fotógrafas, manifestações de surpresa (mesmo que agradável) e alguma forma de conflito face à norma, isto é, face à equivalência simbólica entre artista e o género masculino.

\section{NotAS FINAIS}

Desde a sua própria época, sobressai a ideia de Maria Pia como "alguém que se sabe apresentar como uma rainha", que é por isso naturalizada como objeto dos olhares, e das imagens, fazendo furor com "o seu porte elegante" em todas as ocasiões públicas em que se apresenta (Vicente, 1988). Posicionamento que tendeu a ser repetido e talvez até ampliado na historiografia geral mas também no colecionismo fotográfico. Este "apetite" colecionista justifica-se pela maior circulação de imagens com a rainha (face à circulação das imagens produzidas pela rainha), mas também porque isso corresponde às expetativas inquestionadas que perduram sobre a visualidade.

De facto, na nossa historiografia é essa faceta de fotografada, de objeto do olhar dos fotógrafos, que tem merecido mais atenção (Vicente, 1988; Andrade, 2011; Lopes, 2011). Isto não acontece por acaso mas porque existe uma construção cultural dos olhares que tem género. Lembremo-nos do filme de Antonioni "Blowup!" que exemplifica de forma expressiva essa definição do fotógrafo como sendo um homem (e também, frequentemente, branco) enquanto as fotografadas são (no filme, exclusivamente) muIheres. Como referia John Berger: "os homens agem, as mulheres aparecem" (Berger, 1982, p. 51).

No caso das monarquias, a preponderância da representação de si é regra, no quadro da "esfera pública representativa" (Habermas, 1988), tanto para reis como para rainhas, príncipes e princesas. No Novidades (1900), noticiava-se assim a inauguração da exposição a que nos referimos em cima: "a Sra D. Maria Pia trajava uma toillette muita rica, de veludo roxo com guarnições de peles e o Sr. Infante vestia a sua farda de tenente coronel de artilharia". E não escapava ao público: "as galerias estavam apinhadas de senhoras, que se poseram de pé à chegada da família real, sendo nesse momento, verdadeiramente belo, o aspeto da sala". Quem seriam estas senhoras? Estariam lá para ver os reis ou seriam verdadeiras aficionadas pela arte fotográfica? Ficamos sem saber.

A diversidade de formas em que a rainha Maria Pia se fez representar e a multiplicidade de autores fotográficos, torna estas suas imagens um tema da maior importância para a história da fotografia portuguesa. Contudo, o mesmo poderia ser dito das suas atividades artísticas. Estas têm sido mencionadas, mas pouco mostradas e debatidas. A ausência desse outro lado, revela as dificuldades da historiografia portuguesa em confrontar os seus próprios modelos de construção do passado e em interrogar-se sobre os processos de invisibilização. É frequentemente esse o caso quando falamos das atividades das mulheres. E como constatamos, até mesmo das rainhas. 


\section{REFERÊNCIAS BIBLIOGRÁFICAS}

AA.VV. (2015). Tirée par...A rainha D. Amélia e a fotografia. Catálogo da exposição. Lisboa: Documenta.

AA.VV. (2016) Um Olhar Real. Obra artística da rainha D. Maria Pia - desenho, aguarela e fotografia. Lisboa: Palácio Nacional da Ajuda e Imprensa Nacional Casa da Moeda.

A exposição nacional de photographia (1900, fevereiro). Boletim Photographico, 2, 17-29.

A Exposição Nacional de Photographias (1899, 31 de dezembro). Novidades.

A mulher e a fotografia (1909, fevereiro). Echo Photographico, 36, pp. 18-19.

A rainha de Inglaterra, amadora de photographia (1905, abril). Boletim Photographico, 64, p. 50.

Andrade, M. do C. R. de (2011). Maria Pia de Sabóia. Fotobiografia. Lisboa: INCM e Instituto dos Museus e da Conservação/Palácio da Ajuda.

Barnes, C. W. (1889, dezembro) Why Ladies Should be Admitted to Membership in Photographic Societies. The American Amateur Photographer, 1(6), 223-224.

Barros, J. L. (2009). Amélia Rey Colaço: Fotobiografia. Lisboa: Círculo de Leitores.

Baudelaire, C. (1987). Lettre a M. le Directeur de la Revue Française sur le Salon de 1859. In Du Bon Usage de la Photographie: Une anthologie de textes (pp. 27-35). Paris: Centre National de la Photographie.

Berger, J. (1982). Modos de Ver. Lisboa: Edições 70.

Collin, F. (2010). O feminino na filosofia pós-metafísica. In T. Joaquim (Ed.), Masculinidades/Feminilidades (pp. 17-25). Porto: Edições Afrontamento,

Denny, M. (2009). Royals, Royalties and Remuneration: American and British Women Photographers in the Victorian Era. Women's History Review, 18(5), 801-818.

Denny, M, (2012). Catherine Weed Barnes Ward: Advocate for Victorian Women Photographers. History of Photography. 36(2), 156-171. doi: 10.1080/03087298.2012.654938

Echo Photographico, Jornal Mensal de Sport Photographico (1907, junho). Echo Phographico, 13, capa.

Editorial (1909, janeiro). Echo Photographico, 35, p. 2.

Eu sou o tareco! (1907, março). Echo Photographico, 10, p. 76.

Exposição nacional de photographia (1900, 14 de janeiro). O Século, p. 1.

Fonseca, C. S. (2016). Uma família de fotógrafos. Carlos e Margarida Relvas. Lisboa: Chiado Editores.

Galeria de Amadores Contemporâneos: D. Maria C. Godinho (1907, agosto). Echo Photographico, 15, p. 17.

Galeria de Amadores Contemporâneos: Nathalia Terra (1908, maio). Echo Photographico, 24, p. 89.

Habermas, J. (1988). L'espace publique. Archéologie de la publicité comme dimension constitutive de la bourgeoisie. Paris: Payot.

Hunt, J. D. (2002). The Picturesque Garden in Europe. Londres: Thames\&Hudson.

Jardim, M. do R. (2016). Fotografias de S.M. a Rainha D. Maria Pia. In Um Olhar Real. Obra artística da Rainha D. Maria Pia [Catálogo da exposição homónima] (pp. 167-181). Lisboa: INCM e Palácio da Ajuda. 
Leandro, S. (2011). Boa figura, má figura, sem figura: Mulheres artistas no tempo da $1^{\mathrm{a}}$ República. In Z. O. Castro; J. Esteves \& N. Monteiro (Eds.), Mulheres na Primeira República. Percursos, conquistas e derrotas (pp. 271-318). Lisboa: Ediç̃̃es Colobri.

Lopes, M. A. (2011). Rainhas que o povo amou. Estefânia de Hohenzollern. Maria Pia de Saboia. Lisboa: Círculo de Leitores.

Martins, C. (2005). Arendt: a perspectiva feminina do espaço público? In Livro de Atas do $4^{\circ}$ Congresso da Sopcom (pp. 701-711). Covilhã: Labcom.

McLaughlin, L. (2004). Para além das "esferas separadas": o feminismo e o debate dos estudos culturais/ economia política. In M. J. Silveirinha (Ed.), As Mulheres e os Media (pp. 97-122). Lisboa: Livros Horizonte.

Mendes Flores, T. (2016) A paisagem pitoresca e o daguerreótipo no pensamento geográfico de Alexander Von Humboldt. Ponto de Acesso, 10(3), 4-20.

Mitchell, W.C.T. (1995, dezembro). Interdisciplinarity and Visual Culture. Art Bulletin, LXXVII(4), 540-544.

Mulvey, L. (1989). Visual and Other Pleasures. Bloomington e Indianapolis: Indiana University Press.

Nameghy, K. M. \& Gonzaléz, C. P. (2013). From Sitters to Photographers: Women in Photography from the Qajar Era to the 1930's. History of Photography, 37(1), 48-73.

Photographers at Work, Young Women Becoming Enthusiastic Over the Art (1890, 2 de junho). New York Times, p. 8.

Nochlin, L. (1988). Women, Art and Power, and Other Essays. Nova lorque: Harper\&Row.

Pallier, J. (2006). Maria Pia: a mulher que queria ser rainha. Lisboa: Bertrand Editores.

Pavão, J. M. \& Cerqueira, J. (2007). Maria Pia: Rainha e mulher. Mirandela: João Azevedo Editor.

Pollock, G. (1987). Vision and Difference. Feminism, Feminity and Histories of Art. Massachussets: Methuen Publishing.

Rosenblum, N. (1994). History of Women Photographers. Nova lorque: Abbeville Press.

Sena, A. (1998). História da imagem fotográfica em Portugal-1839-1997. Porto: Porto Editora.

Silva, J. P. N. da (1865), Descrição artística das novas salas do Real Paço d'Ajuda (Obras mandadas executar por Sua Magestade a Senhora D. Maria Pia de Saboia nos seus Reais Aposentos). Lisboa: Thypographia Portuguesa.

Silva, R. H. da \& Monge, M. de J. (2007). 1863-1908, El-Rei Dom Carlos, pintor. Caxias: Fundação Casa de Bragança.

Smith, L. (2015). A Royal Passion: Queen Victoria and Photography. History of Photography, 39(2), 196-198. doi: $10.1080 / 03087298.2015 .1030182$

Tavares, E. \& Medeiros, M. (2015). Tesouros da fotografia portuguesa do século XIX. Lisboa: Edições do MNAC.

Tavares, M. (2011). Feminismos: percursos e desafios (1947-2007). Lisboa: Texto Editores.

Vaz, J. (2016). D. Maria Pia de Saboia. Um olhar real. In Um Olhar Real. Obra artística da Rainha D. Maria Pia. Catálogo da exposição homónima (pp. 11-146). Lisboa: INCM e Palácio da Ajuda. 
Vicente, A. P. (1988). D. Maria Pia e os seus fotógrafos. S.I.: s.n. Cota da Biblioteca Nacional $n^{\circ} 18776$.

Vicente, F. L. (2012). A arte sem história. Mulheres e cultura artística (séculos XVI-XX). Lisboa: Athena.

Vicente, F. L. (Ed.) (2016). Aurélia de Sousa. Mulher artista (1866-1922). Lisboa: Tinta da China.

Wells, L. (2003). The Photography Reader. Londres: Routledge.

Women Who Press the Button (1893, 1 de outubro). New York Times, p. 18.

Woolf, V. (1931). A Room of One's Own. Londres: Hogarth Press.

\section{FinANCIAMENTO:}

Bolsa de Pós-Doutoramento da Fundação para a Ciência e a Tecnologia (SFRH/ $\mathrm{BPD} / 72321 / 2010)$.

\section{Nota BiográFicA}

Teresa Mendes Flores é doutorada em ciências da comunicação pela Universidade Nova de Lisboa (2010). É professora auxiliar na Escola de Comunicação, Artes, Arquitetura e Tecnologias da Informação da Universidade Lusófona desde 1997 e investigadora no CIC.Digital-Pólo FCSH. Investiga nas áreas da fotografia, cinema, cultura visual e estudos de género. Como bolseira de pós-doutoramento, desenvolve uma pesquisa sobre as fotografias produzidas no contexto das expedições científicas portuguesas a África, no final do século XIX. Publicou o livro Cinema e Experiência Moderna (Minerva, Coimbra, 2007) e co-editou o livro Photography and Cinema. Fifty Years of Chris Marker's La Jetée (British Schollars 2015). Integra a equipa editorial da coleção de livros Media e Jornalismo e da Revista de Comunicação e Linguagens. É Vice-Presidente do CECL e membro da Direção da Associação Ibérica de Semiótica.

E-mail: teresa.flores@sapo.pt

Universidade Lusófona de Humanidades e Tecnologias, Avenida do Campo Grande, 376, 1749-024 Lisboa, Portugal

* Submetido: 15-08-2017

* Aceite: 30-09-2017 